\title{
STRUCTURAL CONTROL AND (RE)MOBILIZATION OF THE EXTINCT HAVERI Au-Cu DEPOSIT, SOUTHERN FINLAND
}

\author{
MIKKO NIRONEN
}

NIRONEN, MIKKO 1994. Structural control and (re)mobilzation of the extinct Haveri Au-Cu deposit, southern Finland. Bull. Geol. Soc. Finland 66, Part I, 39-44.

The extinct Haveri Au-Cu deposit is located within mafic metalavas and mafic/ intermediate banded rocks of the Haveri Formation, in the western part of the Paleoproterozoic Tampere Schist Belt. The sulfide-bearing banded rocks display a large $\mathrm{E}-\mathrm{W}$ trending fold structure in magnetic and electromagnetic maps. Field evidence suggest that the $\mathrm{Au}-\mathrm{Cu}$ deposit is in a $\mathrm{F}_{1} / \mathrm{F}_{2}$ fold interferrence pattern in the western core of the large fold. The ore-forming elements concentrated into the $F_{1}$ fold closure during $D_{1}$ deformation. Sulfide-bearing fractures subparallel to $S_{2}$ spaced cleavage indicate slight remobilization during $\mathrm{D}_{2}$.

Key words: copper ore, gold ore, metavolcanic rock, structural controls, mobilization, Proterozoic, Paleoproterozoic, Haveri, Finland

Mikko Nironen, Geological Survey of Finland, SF-02150 Espoo, Finland 


\section{INTRODUCTION}

The Tampere Schist Belt (TSB, Fig. 1) is perhaps the most thoroughly investigated volcanicsedimentary belt of the Paleoproteozoic Svecofennian Domain in Finland. Sederholm (1897) in his classic work studied the well-preserved primary structures of the supracrustal rocks, and later Seitsaari (1951) complemented the petrographic aspect of the schist belt. Recently the igneous, structural, and geochemical characteristics of the TSB have been established (Kähkönen 1987, 1989, Nironen 1989a, 1989b). The extinct Haveri Au-Cu mine is located within mafic metalavas and mafic/ intermediate banded rocks (the Haveri Formation) in the western part of the TSB. Based on the structural and geochemical investigations, the Haveri Formation is thought to represent a small marginal basin within an ancient volcanic arc (Kähkönen and Nironen, in press). The gold potential of the TSB is assessed by several minor, uneconomic Au occurrences (Luukkonen et al. 1992).

During 1942-1960, a total of 1.5 million tons of ore containing $2.8 \mathrm{~g} / \mathrm{ton} \mathrm{Au}$ and $0.37 \% \mathrm{Cu}$ was mined from an open pit and underground (Isokangas 1978). Stigzelius (1944) studied the metallogeny of the ore and petrology of the rocks around the mine. He divided the deposit into iron ore (mainly magnetite), sulfide ore (pyrrhotite, chalcopyrite and magnetite), gold ore, and "shear zone ore" (mainly pyrite). Mäkelä (1980) studied the geochemistry and origin of the ore and the metavolcanic rocks. He considered that the deposit is volcanic-exhalative in origin, and the ore as well as the host rocks have Cyprus-type sulfide deposit characteristics.

The existing reports and studies of Haveri mine, added by field observations by the author, were used in this study to asses the structural control and extent of remobilization of the $\mathrm{Au}-\mathrm{Cu}$ deposit.

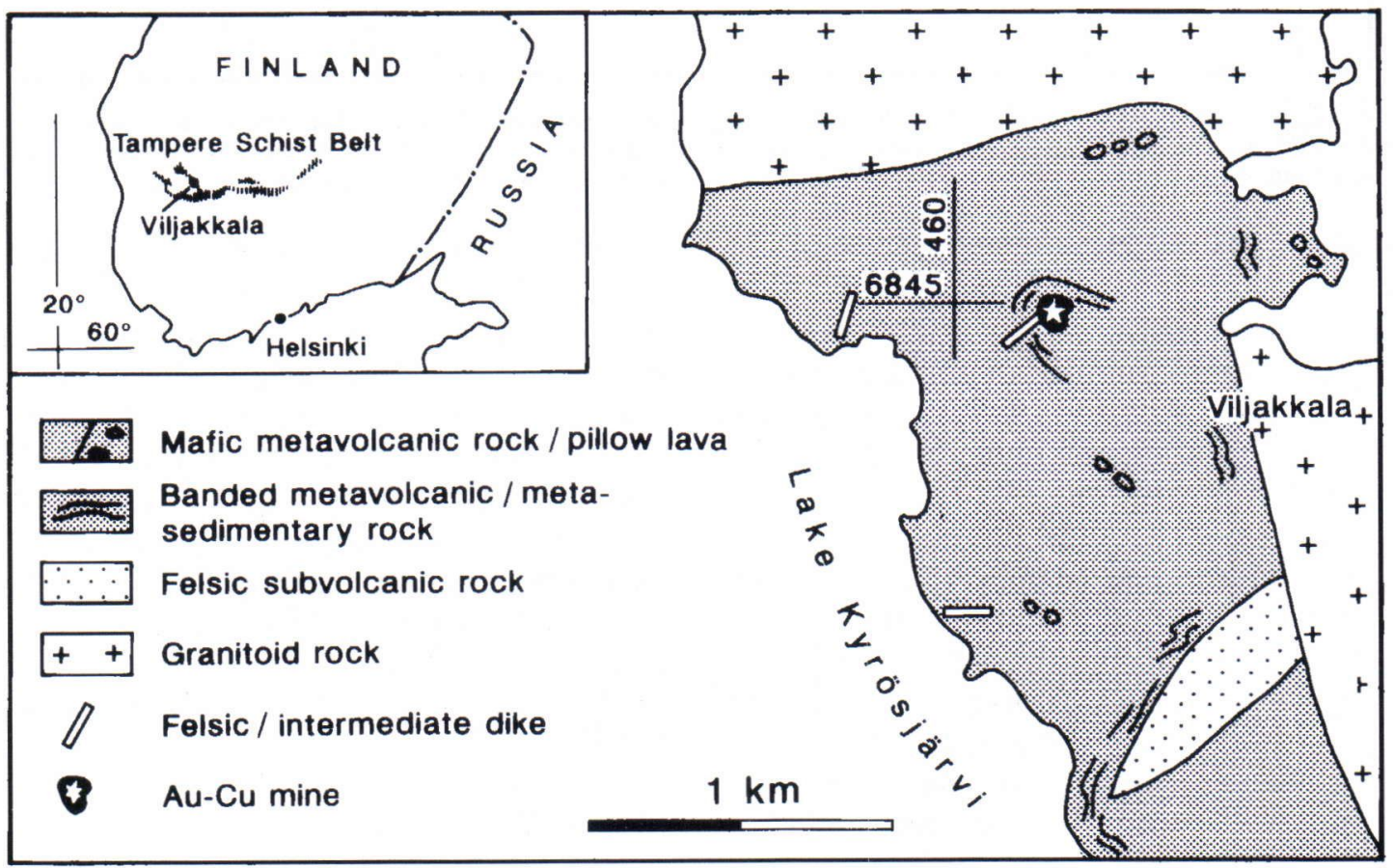

Fig. 1. Gelogical map of the rocks around the Haveri mine in southern Finland. 


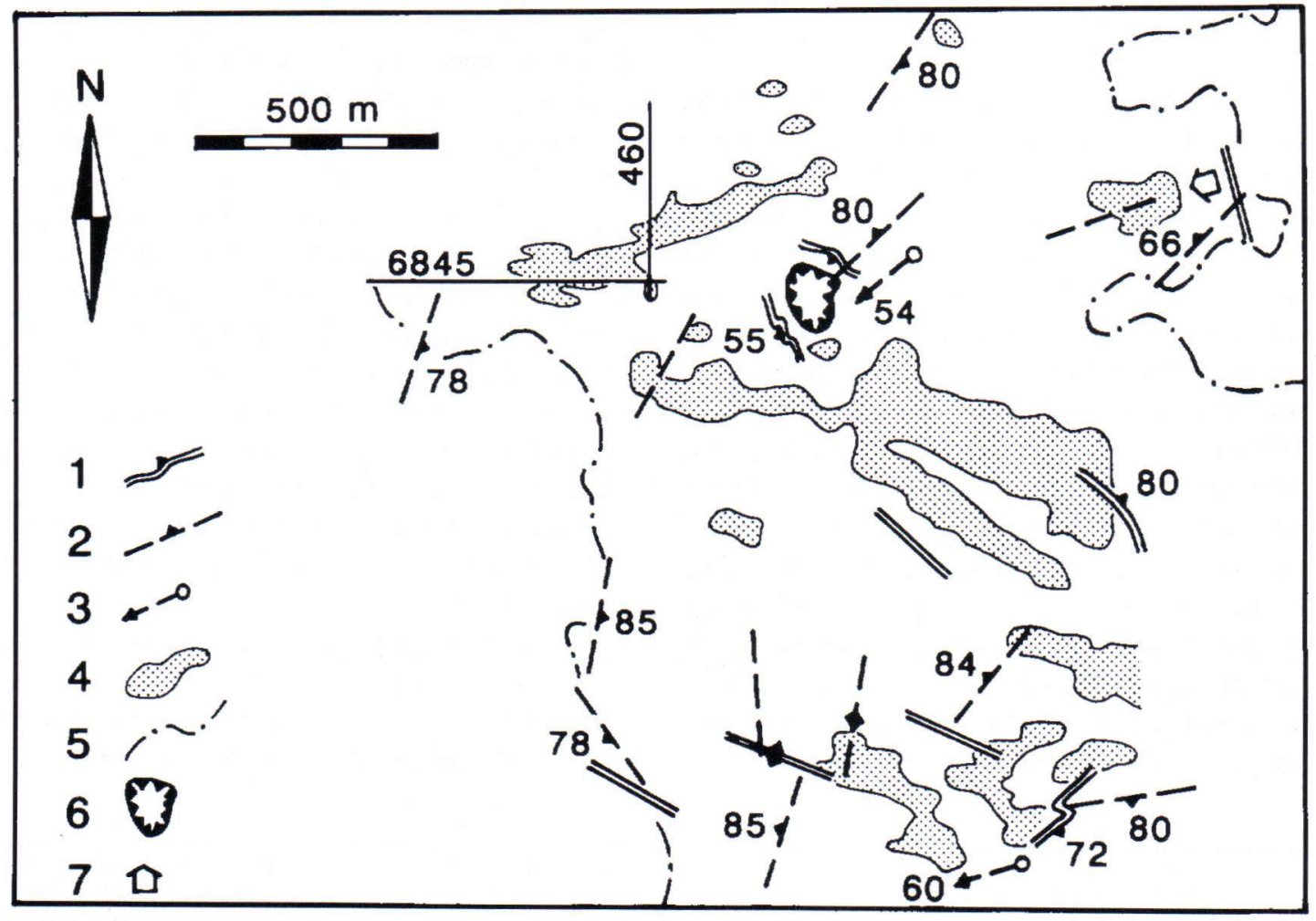

Fig. 2. Structural map around the Haveri mine. $I=S_{0}$ primary layering or $S_{0}-S_{1}$ composite schistosity; $2=S_{2}$ spaced cleavage; $3=F_{2}$ fold axis; $4=$ Area of negative Slingram values (inphase component, coil separation 60 $m$, frequency $1775 \mathrm{~Hz}$; Mäkelä 1977); $5=$ shore line; $6=$ open pit; $7=$ younging of strata.

\section{GEOLOGY OF THE HOST ROCKS}

The Haveri Formation mainly consists of tholeiitic metabasalts, containing breccia and pillow structures in addition to the dominant massive rock type (Mäkelä 1980). Skarn and limestone interlayers, from $10 \mathrm{~cm}$ to over $1 \mathrm{~m}$ wide, have been identified at the mining site. The metabasalts consist of hornblende, plagioclase as the main constituents, and sphene, epidote and quartz as minor constituents. The rock is usually slightly porphyritic, with small plagioclase and uralite phenocrysts. The ore occurs mostly within a breccia-type metalava.

Mafic metatuffs and intermediate metatuffites, named here as banded rock unit, occur as a distinct, 50-200 m wide layer. Because of the characteristic sulfide content, this layer can be detected as a positive anomaly in magnetic and electromagnetic maps (Fig. 2; Kähkönen and Nironen, in press). Plagioclase, biotite, and quartz are the main constituents, and hornblende and chlorite occur in variable amounts (Ollila 1977). Pyrrhotite, pyrite, and occasional chalcopyrite and sphalerite are the suflide minerals in the banded rock unit. Disseminated graphite is also a common costituent.

A dike, dacitic in composition, crosscuts the metavolcanic rocks at the western margin of the open pit. The dacite is a porphyritic rock with plagioclase and quartz phenocrysts. Main constituents are plagioclase, quartz, and biotite (Ollila 1977).

\section{STRUCTURES}

The only evidence for depositional younging is in a pillow-structured metalava east of the Haveri 


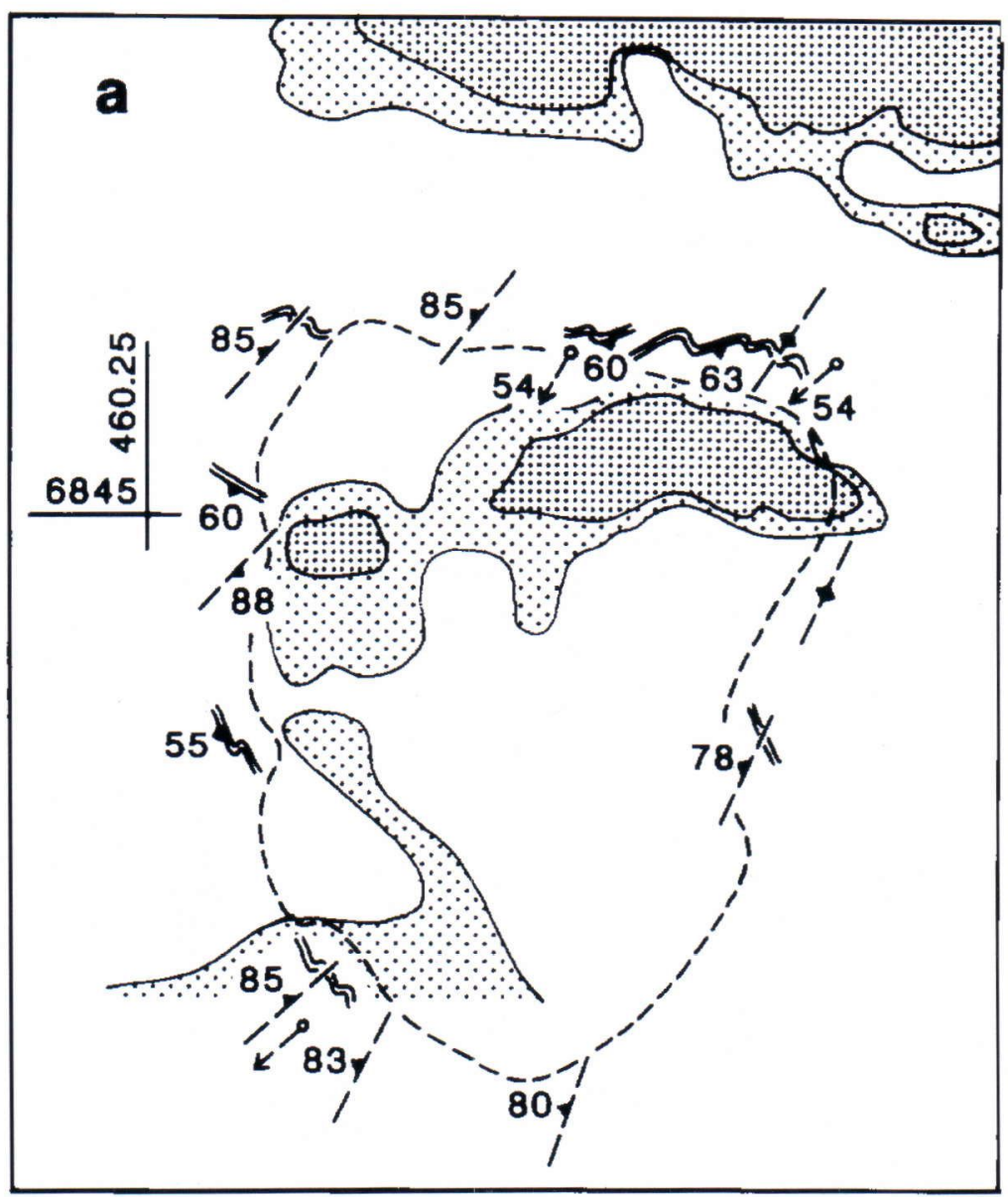

Fig. 3. a) Structures and magnetic anomalies in the Haveri Au-Cu mine. Magnetic anomalies were drawn from Stigzelius 1944, Fig. 37.

mine (Fig. 2). In that area, the "tails" of the pillows and amygdules in the opposite margin of the pillows indicate younging of strata to the west, towards the mine. Unfortunately the area is largely covered by mining waste, hence the stratigraphy is not known around the mine.

The pillow and breccia fragments in the metalavas are often elongated subparallel to the primary layering. In the banded rock unit, a weak biotite/ hornblende orientation can be seen parallel to the banding. In analogy to similar orientation elsewhere in the TSB (Nironen 1989b), this was named $\mathrm{S}_{1}$ scistosity.

Folding can be seen in some of the outcrops in the banded rock unit, e.g., at the northern edge of the open pit (Fig. 3a). Here, $\mathrm{F}_{2}$ fold axes plunge moderately towards the SW. This attitude of the $\mathrm{F}_{2}$ fold axes is consistent with the observations made in this deposit during the mining of the ore (compare Figs $3 a$ and $3 b$ ). Sulfide-bearing fractures subparallel to $\mathrm{S}_{2}$ spaced cleavage occur in the metavolcanic rocks. The dacitic dike crosscuts the banding, but it also contains sulfide-bearing fractures. 


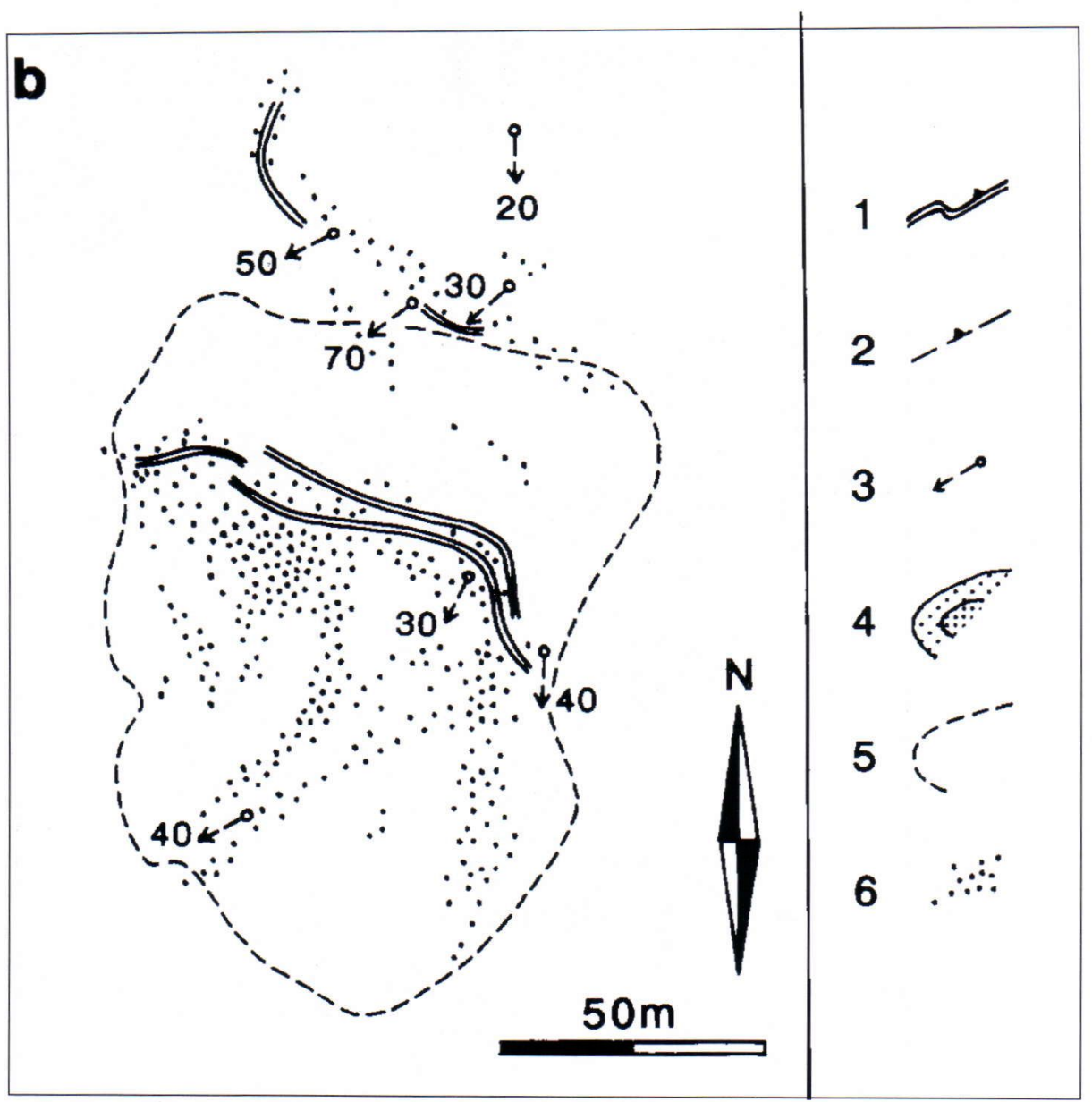

b) Structures and relative gold distribution at $50 \mathrm{~m}$ level below the surface. Drawn from Stigzelius 1944, Figs. 8 and 44. $1=S_{0}$ primary layering or $S_{0}-S_{1}$ composite schistosity; $2=S_{2}$ spaced cleavage; $3=F_{2}$ fold axis; $4=$ contours based on local changes in magnetic vertical intensity (shaded areas show positive anomaly); $5=$ margin of the open pit; $6=$ relative gold distribution at $50 \mathrm{~m}$ level.

\section{STRUCTURAL CONTROL OF THE Au-Cu DEPOSIT}

The actual setting of the ore has been determined using drill core samples (not studied by the author) and old reports. The main ore-forming minerals in the sulfide ore are the pyrrhotite (dominant), chalcopyrite and pyrite (Paarma 1947). According to Mäkelä (1980), the sulfide ore occurs as stockwork-type breccias or fracture fillings which together display folded and streaky structures within the metalavas.
The magnetic and electromagnetic maps show a large E-W trending fold closing west of the Haveri mine. This fold can also be seen in the banded rock unit (Figs 2 and 3). This structure was interpreted by Kähkönen and Nironen (in press) either as an $\mathrm{F}_{1}$ fold or as an early stage fold of progressively rotated $\mathrm{F}_{2}$ folding. Considering the almost orthogonal axial planes of the large fold and mesoscopic $\mathrm{F}_{2}$ folding, the deposit seems to be in a type 3 fold interference pattern (Ramsay 1962).

The "shear zone ore" contains some gold in addition to pyrite and other sulfide minerals 
(Stigzelius 1944). Also chlorite-bearing fissures with secondary pyrite have been reported (Paarma 1947). However, the location and orientation of these zonal mineralizations are unknown.

\section{DISCUSSION}

Stigzelius (1944) stated that the Haveri $\mathrm{Au}-\mathrm{Cu}$ ore is epigenetic, and the mineralizing elements originated from the adjacent granitoid rock. In contrast, Mäkelä (1980) considered that the ore is syngenetic. According to Mäkelä (1980), the ore-forming elements were leached from the basaltic rocks and were precipitated within flow breccia close to the magma/sea-water interface.

The setting of the deposit in the fold closure is

\section{REFERENCES}

Isokangas, P., 1978. Finland. In: Bowie S.H.U., Kvalheim, A. \& Haslam, H.W. (eds): Mineral Deposits of Europe, Vol 1: Northwest Europe. The Institution of Mining and Metallurgy, The Mineral Society, Dorking, 39-92.

Kähkönen, Y., 1987. Geochemistry and tectonomagmatic affinities of the metavolcanic rocks of the early Proterozoic Tampere Schist Belt, southern Finland. Precambrian Research 35, 295-311.

Kähkönen, Y., 1989. Geochemisrty and petrology of the metavolcanic rocks of the early Proterozoic Tampere Schist Belt, southern Finland. Geological Survey of Finland, Bulletin 345, 107 pp.

Kähkönen, Y. \& Nironen, M. (in press). Supracrustal rocks around the Paleoproterozoic Haveri $\mathrm{Au}-\mathrm{Cu}$ mine, southern Finland: evolution from a spreading center to a volcanic arc environment. Geological Survey of Finland, Special Paper 19.

Luukkonen, A., Grönholm, P. \& Hannila, T., 1992. Main geological features of certain gold and tungsten-tin-gold prospects in Southern Finland. Geological Survey of Finland, Report of Investigation 113, 90 pp. (in Finnish, with an English summary.)

Mäkelä, K., 1977. Viljakkalan Haverin malminetsintätyöt 1976/1977. Research report, Outokumpu Oy, 4 pp. (in Finnish).

Mäkelä, K., 1980. Geochemistry and origin of Haveri and Kiipu, Proterozoic strata-bound volcanogenic gold-copper and zinc mineralizations from interpreted as the result of mobilization of disseminated sulfides in the banded rock unit and metalavas during $\mathrm{D}_{1}$ deformation, and concentration in a deforming breccia-type metalava with small extensional "pockets".

In the open pit, $\mathrm{Cu}$ and $\mathrm{Au}$ displayed overlapping zonal distribution patterns subparallel to $\mathrm{S}_{2}$ (Stigzelius 1944, Figs 43 and 44; Fig. 3b). This suggests that the ore was slightly remobilized during $\mathrm{F}_{2}$ folding. Moreover, the sulfide-bearing fractures subparallel to $\mathrm{S}_{2}$ are an expression of remobilization. Since sulfide-bearing fractures occur also in the dike, the latter was injected before the end of $\mathrm{D}_{2}$ deformation. Possibly heat brought by the injection of the dike during $\mathrm{D}_{2}$ remobilized sulfides which concentrated into $\mathrm{D}_{2}$ fractures.

southwestern Finland. Geological Survey of Finland, Bulletin 310, $79 \mathrm{pp}$.

Nironen, M., 1989a. Emplacement and structural setting of granitoids in the early Proterozoic Tampere and Savo Schist Belts, Finland-implications for contrasting crustal evolution. Geological Survey of Finland, Bulletin 346, 83 pp.

Nironen, M., 1989b. The Tampere Schist Belt: structural style within an early Proterozoic volcanic arc system in southern Finland. Precambrian Research 43, 23-40.

Ollila, H., 1977. Haverin kaivoksen ja sen lähiympäristön geologiasta. M. Sc.-thesis, University of Helsinki, Department of Geology, 51 pp. (in Finnish)

Paarma, H., 1947. Haverin kiisumalmin mineraaliparageneesi. M. Sc.-thesis, University of Helsinki, Department of Geology, 59 pp. (in Finnish)

Ramsay, J.G., 1962. Interference patterns produced by the superposition of folds of similar type. Journal of Geology 70, 466-481.

Sederholm, J.J., 1897. Über eine archäische Sedimentformation im Südwestlichen Finnland und ihre Bedeutung für die Erklärung der Entstehungweise des Grundgebirges. Bulletin de la Commission Géologique de Finlande 6, 254 pp.

Seitsaari, J., 1951. The schist belt Northeast of Tampere in Finland. Bulletin de la Commission Géologique de Finlande 153, 120 pp.

Stigzelius, H., 1944. Über die Erzgeologie des Viljakkalagebietes im südwestlichen Finnland.Bulletin de la Commission Géologique de Finlande 134, 91 pp. 